\title{
The Cosmopolitan City: Music and Mediation during the European Capital of Culture Event
}

\author{
Simone Krüger
}

\begin{abstract}
This chapter is about the rebranding of post-industrial Liverpool as a cosmopolitan city - The World in One City - prior to and during its celebrations as a European Capital of Culture in 2008. It places specific focus on mediated knowledge, which sought to form cosmopolitan memories of remarkable and symbolically important places and events associated with the city of Liverpool. The chapter's emphasis on mediation is significant, as almost all knowledge of the world is a knowledge entirely mediated, and consequently our understanding of the world is built largely on constructive representations by the media and creative industries (Hall 1997). The chapter's focus on mediation is also important, as an integral component of Liverpool's ECOC status involved its (mediated) marketing and promotional strategy, whose main objective was the promotion of the city and its image, and the ECOC's events and attractions. This chapter illustrates this strategic re-branding of Liverpool as a cosmopolitan city with special emphasis placed on musical events and activities. It demonstrates how the city's musical heritage was constructed into a narrative that presented contemporary Liverpool as an ethnically and socially diverse, as well as inclusive and tolerant festival city. At the centre of Liverpool's new place brand was thus a particular form of diasporic cosmopolitanness representative of neo-Kantian cosmopolitanism that framed culture in more socially-directed ways. Yet in doing so, Liverpool's 'multiethnic' identity was promoted in the media campaigns as a positive signifier of an exoticised and Orientalist form of multiculturalism that reinforced authenticity, difference and otherness in the depictions and representations of certain groups of people. Thus official place branding initiatives via media and promotional strategies can lead to stereotyped representations of places that construct and reinforce a certain acceptable image of the city, informed most notably by the politics of race, class and other cultural difference.
\end{abstract}


[forthc. 2014]. "The Cosmopolitan City: Music and Mediation during the European Capital of Culture Event". In Media and Cosmopolitanism, edited by Aris Mousoutzanis, Ruxandra Trandafoiu and Aybige Yilmaz. New York: Peter Lang.

\section{Introduction}

European Capitals of Culture (ECOC) are now an accepted and important part of the European cultural scene. Since its origin in 1985, some 38 cities have secured and implemented activities under the ECOC banner (or its predecessor). In some ways, ECOC have indeed become 'big business', attracting growing attention and subject to increasing scrutiny. (ECOTEC 2009: 1)

The European Capital of Culture programme, an initiative launched by the European Union in 1985, operates particularly in the context of broad urban regeneration of de-industrialising cities by utilising cultural capital for long-term economic and social change towards a secure post-industrial future (Griffiths 2006: 418). The purpose of the ECOC title is both to highlight existing cultural excellence and to encourage cities to develop and innovate through culture to enhance regeneration, social inclusion, education and business (Isaacs 2003: 2), whereby culture is regarded as a wide variety of popular and 'high' art expressions that resides in and grows out of the daily lives of a city's local communities. The ECOC programme thus plays an important role in urban economic and cultural reconstruction strategies for deindustrialising cities in Europe (Richards 2000).

More specifically, the ECOC programme can be seen as an effort to develop, promote and market a place brand (Evans 2003: 425-29; Hjortegaard 2010; Nobili 2005) in order to enhance a city's image, to attract tourists and to stimulate regeneration. Place branding first occurred in the late 1970s in the US as a response to the changes in the global economic system, which left key industrialized centres in the West in decline that had acquired negative images symbolising dereliction and degradation (Ward 1998: 186). City administrators responded by developing image make-over strategies to construct a dynamic place imagery in order to reimage, reinvent and reposition their city, reflected in the various strategies that moved from selling places to place marketing and later place branding (Young, Diep and Drabble 2006: 1691; see also Dinnie 2004), which is now a global phenomenon and evident in cities around the world (Evans 2003). The current age of city marketing is thus characterised by concerns with economic development and urban regeneration policies, with 
[forthc. 2014]. "The Cosmopolitan City: Music and Mediation during the European Capital of Culture Event". In Media and Cosmopolitanism, edited by Aris Mousoutzanis, Ruxandra Trandafoiu and Aybige Yilmaz. New York: Peter Lang.

declining industrial cities' economies shifting away from production and towards consumption.

In 2008, Liverpool was awarded the title of European Capital of Culture in an effort to reposition the city as a World Class City and rebrand Liverpool (Anderson and Holden 2008: 151), specifically under the banner The World in One City in reference to and celebration of its cosmopolitanism, ${ }^{1}$ and so to continue the city's place marking efforts that took shape since the 1990s. ${ }^{2}$ Liverpool's overall motivation for bidding to become ECOC was threefold: Create, a $21^{\text {st }}$ century creative city; Participate, a cultural city defined by participation; Regenerate, a city made whole through cultural expression (Isaac 2003: 4). At the heart of the Liverpool ECOC vision was an aspiration to regenerate the city nationally and globally, to improve the city's reputation and reposition Liverpool as a world class city. This was underpinned by a desire to engage with and inspire residents of the city, and thus to empower an inclusive and dynamic community.

The long-term benefits are envisaged as making the city a better place to visit, live, work, and invest in, with the overall legacy of the award being a new Liverpool. (Isaac 2003: 5)

An integral component of Liverpool's ECOC status involved its marketing and promotional strategy, which included a local campaign under the theme it's our time, it's our place aimed at enhancing local engagement, and a national/international campaign that sought to reposition Liverpool in people's perceptions. The main objective of Liverpool's media activities was thus the promotion of the city and its image, notably places and heritage sites of global significance, and the promoting of the ECOC's events and attractions. This mediated knowledge aimed at forming 'cosmopolitan memories' (Barthel-Bouchier and Hui 2007) of remarkable and symbolically important places and events associated with the city of Liverpool. A local advertising agency was commissioned to develop a logo, brand and feel for the ECOC (ECOTEC 2009: 64-65). The bid that secured Liverpool's ECOC status was led by the Liverpool Culture Company Limited (LCCL), the managing and commissioning body for the ECOC event, which was set up by Liverpool City Council (LCC), the governing and administrative body of the city. ${ }^{3}$ In the narrative constructed by LCCL, Liverpool was represented as a premier European city aspiring to become a true Festival City (LCCL 2002: 100). 
[forthc. 2014]. "The Cosmopolitan City: Music and Mediation during the European Capital of Culture Event". In Media and Cosmopolitanism, edited by Aris Mousoutzanis, Ruxandra Trandafoiu and Aybige Yilmaz. New York: Peter Lang.

The place rebranding of Liverpool as a city that is 'both local and international - The World in One City' (LCCL 2002: 1) that took shape in the marketing and promotional campaigns prior to and during its year as European Capital of Culture echoed journalistic and academic discourses that often accredit Liverpool's port as a source of movement, migration and settlement - a centre for imperial trade and human transit, 'the world port city, former capital of the slave trade and gateway of empire' (Belchem 2005: 152) - as the main influence on Liverpool's cosmopolitan identity (e.g., Brocken 2010; Cohen 1991, 2007; DuNoyer 2007: xi). This chapter, which is informed by urban ethnographic research conducted during 2008 into the interrelatedness between music, mediation and place, ${ }^{4}$ explores these notions by focusing on the mediation of cosmopolitanism in the place branding of Liverpool as European Capital of Culture under the banner The World in One City.

\section{Constructing the Cosmopolitan City ${ }^{5}$}

Liverpool is a veritable cocktail of cultures; Irish, Welsh, Scots as well as English; Jewish, Muslim, Hindu; Chinese, Greek, Italian, Spanish; more recently Caribbean, Somali and Yemeni; and most recently refugees and asylum seekers from the Balkans and the Middle East. Liverpool accords to every person the right to be themselves. (LCCL 2002: 1102)

In the bid that won the ECOC title, LCCL represented Liverpool - a cocktail of cultures - as an ethnically and socially diverse, as well as a tolerant city, and emphasised the role of culture for community integration alongside more economic goals. Central to Liverpool's bid was local community commitment and participation of traditionally under-represented groups and individuals, a priority that had grown out of prior consultations with local communities who felt excluded and under-funded (LCCL 2002: 701), and which was thus accorded the highest priority both prior to and during the ECOC event (ibid.: 501). ${ }^{6}$ The bid emphasised support for disadvantaged communities and included events designed to appeal to a wide cross section of people (Isaac 2003: 5). In doing so, the narrative constructed by LCC placed a marked emphasis on the city's people, notably from the 'Scouse', Irish, African, Arabic and Chinese communities, and branded Liverpool as an 800-year old city that embraces and celebrates its cultural diversity, a cosmopolitan city with apparently the longest established truly cosmopolitan communities in Britain (LCCL 2002: 1102). 
[forthc. 2014]. "The Cosmopolitan City: Music and Mediation during the European Capital of Culture Event". In Media and Cosmopolitanism, edited by Aris Mousoutzanis, Ruxandra Trandafoiu and Aybige Yilmaz. New York: Peter Lang.

A promotional film titled Liverpool: World in One City accompanied the city's campaign bid to become ECOC, ${ }^{7}$ described as an 8 -minute 'postmodern city symphony' that delivers a 'vibrant image of a global, multi-cultural city' (Roberts 2010: 200). In it, fast-cut visual depictions of the city's iconic buildings and architectural landmarks are interspersed with dizzying images of festivals, performances and music venues, notably the super brand Cream, ${ }^{8}$ overdubbed with an eclectic classical and popular music mix and a commentary (by actress Cathy Tyson) of positive catchwords to describe the city and its people. All of this is underpinned by a marked emphasis on consumption, celebrity culture and lifestyle. The audio opens with photographic camera sounds and contemporary classical music played by the RLPO to set the scene for the dizzying snapshot-like visual collage of the film, moving into a hybrid musical composition that blends classical and pop, most notably Liverpool band Echo and the Bunnymen's songs 'Silver' and 'Never Stop'. Taking its lead from the marketing tagline for the bid The World in One City, and thereby constructing and reinforcing Liverpool's image as a cosmopolitan city, the film emphasises LCC's commitment towards cultural diversity and inclusivity,

flooding (or drowning) the cultural landscapes of the city with an aesthetic designed not so much to extrude specificity of place and identity, as to ensure that all conceivable pockets or lacunae (whether cultural, ethnic or religious) are representatively 'filled'. (Roberts 2010: 202)

This emphasis on cultural diversity and integration can be duly contextualised within European policy making, where diversity is usually related to ethnicity (Cohen 2012: 586). For instance, Liverpool Samba School (Figure 1), which was founded in 1995, formed the Liverpool Carnival Company in 2007 and launched the first annual Brazilian samba carnival parade in Liverpool as part of the city's Capital of Culture celebrations with an audience of ca. 30,000 people, ${ }^{9}$ adds an ethnically-informed cosmopolitan dimension to the film's celebration of diversity and inclusively, which is further reinforced by the narrator's catchphrases: 'Talent. Innovation. Fashions. Music. Humour. An unmistakable cultural identity. The World in One City.' (Cathy Tyson, River Media 2002). 
[forthc. 2014]. "The Cosmopolitan City: Music and Mediation during the European Capital of Culture Event". In Media and Cosmopolitanism, edited by Aris Mousoutzanis, Ruxandra Trandafoiu and Aybige Yilmaz. New York: Peter Lang.

\section{<INSERT FIGURE 1 HERE>}

Figure 1. Still from Liverpool: World in One City (River Media 2002), here depicting the highly sexualised dancers of 'multi-ethnic' backgrounds during the Brazilian samba carnival.

The film continues to highlight Liverpool's rich musical potpourri by juxtaposing images of the Royal Liverpool Philharmonic Orchestra conducted by Carl Davis; festivals like Africa Oyé and Matthew Street Festival; Liverpool-born The Beatles, Gary Christian and Atomic Kitten; and non-Scouse celebrities like Sophie Ellis-Bexter, Posh Spice, Francis Rossie and Rick Parfitt, Louise Nurding Redknapp, Blue, Ash and Lionel Richie in a celebration of Liverpool's status as the 'World Capital of Pop' and 'Liverpool's impact on world music', and thereby constructs an image of Liverpool where popular and multi-ethnic cultures have equal status to European 'high' art. In the bid that won the ECOC title, LCCL thus represented Liverpool as a diverse and inclusive festival city based on its 'multi-ethnic' heritage resulting from the movement, migration and settlement of people. The branding of Liverpool as a vibrant cosmopolitan festival city was reinforced subsequently in LCCL's event management and media campaigns accompanying the 2008 ECOC year.

\section{Performing the Cosmopolitan City}

Liverpool's ECOC programme effectively combined both a major cultural festival and cultural mega event (Langen and Garcia 2009: 7-8), which involved a vast programme of activity that included around 300 official 'Liverpool 08' events themed around music, literature, art, streets, stage, participate, conversation, sport and exploring, alongside thousands of unofficial events and activities, totalling around '7,000 cultural events, activities and projects... attended by over 15 million people' and thus making it 'one of the most extensive ECOC programmes to date' (ECOTEC 2009: 65). In considering music, specifically, the Liverpool ECOC programme featured an impressive range of musical activities, underpinned by the desire to feature a nuanced range of international, national and local artists with a strong focus on community access and participation (Garcia, Melville and 
[forthc. 2014]. "The Cosmopolitan City: Music and Mediation during the European Capital of Culture Event". In Media and Cosmopolitanism, edited by Aris Mousoutzanis, Ruxandra Trandafoiu and Aybige Yilmaz. New York: Peter Lang.

Cox 2010: 14). Musical events and activities during 2008 thus differed significantly in scale, musical style and multicultural nature (see also Krüger 2013: 141-43), which is reflective of LCCL's more inclusive and cultural concerns in opposition to purely economic objectives surrounding the ECOC event (see, e.g., Richards 2000). For this reason, more than $70 \%$ of cultural activities were free (ECOTEC 2009: 59), whilst LCCL also sought actively to involve the local music scene that was either inspired by the ECOC title itself or promoted through 'official' efforts towards cultural participation via, for instance, the Creative Community Programme and included community-based projects by local artists and organizations:

The Creative Communities Programme is crucial in making sure that the promise of 'inclusive community participation' which helped win the bid is now fully delivered.... The Culture Company is committed to building community enthusiasm, creativity and participation in 2008. (LCC 2008: 11)

In other words, LCC sought to deliver an inclusive, multicultural programme of musical events and activity, evident in the vast number of community-based projects. This intensive 'public engagement programme', which included Creative Communities, Open Culture, the 08 Welcome Programme and the Volunteer Programme, consisted of local initiatives, events, competitions and festivals, which attracted predominantly local participants and audiences alongside minimal media coverage. Among these activities was the Open Culture initiative that engaged around 6,300 local individuals and organizations (ECOTOC 2009: 66).

Under the banner 'community inclusion' also included were multicultural festivals like Africa Oyé and the Arabic Arts Festival, although these events were already well-established and would have been held even without Liverpool's ECOC status. For instance, Africa Oyé is the largest African music festival in the UK featuring international bands and musicians from the African diaspora, which is held annually over two days in Sefton Park, popularised with 
[forthc. 2014]. "The Cosmopolitan City: Music and Mediation during the European Capital of Culture Event". In Media and Cosmopolitanism, edited by Aris Mousoutzanis, Ruxandra Trandafoiu and Aybige Yilmaz. New York: Peter Lang.

African food, drinks, arts, crafts, and fashion stalls and workshops. Beginning in 1992 as a series of small gigs in the city centre, the event grew steadily, moving to its present Sefton Park location in 2002 to cope with rising audience numbers: The 2007 event attracted an audience of over 40,000 people, which was expected to be exceeded in 2008. As a result, LCC chose to feature Africa Oyé in the bid and accompanying promotional film that won the ECOC title:

... I think it was about 2003 we [Africa Oyé] were told that Liverpool was gonna be bidding for the Capital of Culture, and that Africa Oyé would kind of be at the forefront of that, you know. We were featured in the bid video, you know, as one of the jewels in the crown of the city. (Paul Duhaney; interview transcript, available in Andersson 2011: 107-12; reprinted with permission)

Meanwhile, the four-day Liverpool Arabic Arts Festival was first held in 2002, formerly known as the London Yemeni Festival and held under the auspices of the Yemeni Community Association (YCA). Since then, the festival saw rising national and international success, whilst the 2008 festival attracted nearly 30.000 attendees during 41 events (Qassim und Hassan 2009) and culminated in a performance by raï-star Marcel Khalife, internationally known as Khaled, in the Liverpool Philharmonic Hall. Grouped into the Creative Community Programme, Liverpool Arabic Arts Festival was promoted as follows:

This annual festival of Arabic culture features dance, art, music and more. Performers come from Liverpool's own Arabic population, regional communities and from abroad. The largest event of its kind in the UK, the Arabic Arts Festival has a truly international profile. The festival also extends to outreach work with schools via workshop events. Direct beneficiaries include Liverpool's own Arabic community and those further afield. (LCC 2008: 34-5)

Yet Liverpool's cosmopolitan identity during 2008 became not only defined in terms of ethnicity, thereby focusing exclusively on representations of the city's African, Arabic, Chinese or other 'ethnic' communities. LCCL also evoked a kind of inclusive cosmopolitanism in regards to class, which was achieved by actively involving white communities from less affluent working class areas across the city. For example, LCCL supported fourteen local artists and organizations (from 150 applicants) for the Liverpool Commissions strand by commissioning 'exciting, innovative art projects of international 
[forthc. 2014]. "The Cosmopolitan City: Music and Mediation during the European Capital of Culture Event". In Media and Cosmopolitanism, edited by Aris Mousoutzanis, Ruxandra Trandafoiu and Aybige Yilmaz. New York: Peter Lang.

quality' (ECOTEC 2009: 66) from local artists and organisations. ${ }^{10}$ Noteworthy here is the Rightful Owners of the Song project, led by Liverpool-based musician Jonathan Raisin, which brought together a small number of Liverpool's pub and karaoke singers to perform a one-off concert of pub classics with the Royal Liverpool Philharmonic Orchestra providing the backing music. The staging of local amateur/semi-professional singers in Liverpool Philharmonic Hall and accompanied by the RLPO is noteworthy, as it reflects the city's adopting of EU rhetoric and agendas to promote both the canons of 'high' European art and other forms of 'popular' (working-class) culture (Lähdesmäki 2009). Indeed, whilst some forms of difference, notably white working class culture and areas in the city were not deemed commodifiable or acceptable for inclusion in the new city brand, the staging of white working class culture in the Philharmonic Hall served to turn white working class culture into an acceptable commodity for its marketing imagery:

The event will be a spectacular one-off performance bringing together two significant music cultures within the city... 'The Rightful Owners of the Song' seeks to acknowledge and celebrate 'working' culture. Working class. A manual labour tradition.... To place this economically impoverished musical culture in relation to the incredible richness of resources available to a Symphony orchestra offers the possibility of exposing and bridging such cultural 'rifts'. In this sense, the project is a reflection on the processes of 'dereliction' and 'regeneration'. (Project Synopsis, provided to author by Jonathan Raisin, 2008)

Moreover, the highlighting of Liverpool's 'high' European art culture alongside an emphasis on inclusivity and diversity is particularly important in discussions surrounding the construction of the cosmopolitan city in the context of European self-understanding, within which the European Caputal of Culture event must be placed, given that it is sponsored by the European Union and thus informed by EU policy and agendas (Lähdesmäki 2009). ${ }^{11}$ European cosmopolitanism is regarded 'a name for sophistication' (Calhoun 2009: 637) where the measure for sophistication is European elitist culture, yet also being underpinned by ethical universalism and an embrace of diversity, human rights activism and humantiarian assistance. This form of cosmopolitanism, informed by 'reflexive modernisation' and neoKantian ethical universalism, reemerged as an increasingly important dimension of European self-understanding during the 1990s, which 'simultaneously marked an ethical stance and an 
[forthc. 2014]. "The Cosmopolitan City: Music and Mediation during the European Capital of Culture Event". In Media and Cosmopolitanism, edited by Aris Mousoutzanis, Ruxandra Trandafoiu and Aybige Yilmaz. New York: Peter Lang.

understanding of this ethical stance as a measure for being 'more civilized" (ibid.: 645-46; see further Delanty 2008: 223-25). Yet the coupling of Enlightenment culturalism and universalistic ethics also represents a paradox, as it excludes and even rejects those groups of people who are 'inadequately cosmopolitan' (ibid.: 649), an issue I will return to in the chapter's conclusion.

\section{Orientalism, Exoticism and Stereotyping Scousers}

So far, I have argued that the brand Liverpool under the theme The World in One City was actively constructed and promoted in the media campaigns accompanying the ECOC event as a positive signifier of the city's cosmopolitan identity. The official narrative thereby condensed Liverpool's 800-year history into an easily promotable image:

Take a closer look! Almost eight centuries have been shaping the diversity of peoples, influences and unique culture that make Liverpool the place it is today and the place it will be tomorrow. (Cathy Tyson, River Media 2002)

However, images in the official Liverpool 08 programme often featured orientalist representations of people of Indian, Arabic or African descent (Figure 2), whilst slogans like 'wondrously diverse' and 'melting pot' used in the backgrounds of most promotional materials romanticized and celebrated difference and otherness, all of which reaffirm a certain narrative of collective memory and imaged diversity that became the pinnacle of Liverpool's place brand The World in One City. Thus Liverpool's 'multiethnic' identity, most notably from the African, Arabic, Chinese, and Indian communities, was actively used and promoted in the media campaigns accompanying the ECOC event as a positive signifier of an exoticised and Orientalist form of multiculturalism that sought to stage and museumise Liverpool's diverse cultural heritage. 
[forthc. 2014]. "The Cosmopolitan City: Music and Mediation during the European Capital of Culture Event". In Media and Cosmopolitanism, edited by Aris Mousoutzanis, Ruxandra Trandafoiu and Aybige Yilmaz. New York: Peter Lang.

Figure 2. Liverpool 08 programme depicting young Arab men in turbans holding large daggers, similar to the characters in 1001 Nights and Aladdin, photographed in the garden space of the Bluecoat (08 Liverpool ECOC 2008: 56; published by Liverpool City Council and reproduced with permission).

Thus whilst representations by ethnic migrant groups are clearly evident in the rebranding of Liverpool as a cosmopolitan city, the agendas adopted by LCCL also created an official culture (Jones and Wilks-Heeg 2004) that reinforced authenticity, difference and otherness in the depictions and representations of these groups. For example, in regards to the representations of Liverpool's Arabic community, the city chose to mediate local Yemeni culture that is 'traditional' and in some way 'other' in contrast to modern life in Liverpool (Figure 2), rather than to emphasise modern popular culture, as represented by the internationally-renowned Algerian raï-singer and superstar Khaled (Marcel Khalife) who performed in the Liverpool Philharmonic Hall on 12 July 2008. Whilst Khaled's performance was regarded to be the highlight of the Liverpool Arabic Arts Festival that year (Qassim und Hassan 2009), the concert was not featured in any of the official Liverpool 08 promotional materials (except a negligible inclusion in the festival programme on page 8), a fact that shows that Liverpool's Arabic community was asociated and reconstructed through assocations with otherness that is defined in terms of locality, authenticity and the past.

Meanwhile, other promotional materials like the official brochure The Art of Inclusion: Liverpool's Creative Community (LCC 2008) similarly tended to emphasise Orientalist representations of Arabic culture, here via an illustration of a female belly dancer accompanied by a traditional daf-player against the photographic backdrop of the inside of the Palm House in Sefton Park (Figure 3). Such depictions clearly reinforce prejudiced Orientalist views of gender roles in the Arabic Middle East (Said 1978). Besides the problematic fact that such representations re-emphasise authenticity, difference and otherness, that Orientalism played a role in the city's official representations of the Arabic community is also controversial, as belly dancing and other performances like, for instance, the 'Middle Eastern Dance Bonanza' held on 17 July 2008 were strongly scorned by the local Arabic community and even boycotted, for example when a large group of Arabic families left the 
[forthc. 2014]. "The Cosmopolitan City: Music and Mediation during the European Capital of Culture Event". In Media and Cosmopolitanism, edited by Aris Mousoutzanis, Ruxandra Trandafoiu and Aybige Yilmaz. New York: Peter Lang.

contemporary dance performance 'Shifting Sands', held in the Bluecoat on 18 July 2008, as it featured scantily dressed female dancers.

\section{$<$ INSERT FIGURE 3 HERE $>$}

Figure 3. A page from the official brochure The Art of Inclusion: Liverpool's Creative Community (LCC 2008) to promote Liverpool Arabic Arts Festival as part of the Creative Community Programme. (Published by Liverpool City Council and reproduced with permission)

The fact that Liverpool's Arabic or African heritage and the staging of this heritage during festivals featured strongly in promotional efforts is important, as it taps into the narratives spun around the concept 'Liverpool' as The World in One City, which served the strategic performance of cosmopolitanism. Here, pluralism and difference were turned into a spectacle for consumption through 'museumizing' culture (after Appadurai 1990: 304), creating a staged environment where, for instance, African musicians like Nigerian Oludele Olaseinde and Senegalese Mamadou Diaw felt the need to perform their ethnicity to resemble that of the festival (e.g., Africa Oyé) and thereby tap into preconceived assumptions about 'authentic' African music in order to be featured on local stages (Andersson 2011), ${ }^{12}$ a common mechanism used in official narratives surrounding cosmopolitanism today. This also involved the representation of dancers and musicians in highly sexualised and exoticised clothing and accessories (Figures 1 2and 4), which signified affiliation to another, different music culture and thereby reinforced ideas of authenticity, tradition and the exotic other, as the musicians and dancers who looked 'right' resembled the same origin as the music culture depicted, at least in the eyes of Western/European audiences. And this choice of representation also alienated the intended audiences in their spectatorship positions from the musicians - by their stance of gazing at the other.

Representations of African diasporic culture in official promotional materials surrounding Liverpool ECOC also projected a concern with 'simple' or 'old' cultures, signified by images of half-dressed dark-skinned people playing African drums made from natural resources 
[forthc. 2014]. "The Cosmopolitan City: Music and Mediation during the European Capital of Culture Event". In Media and Cosmopolitanism, edited by Aris Mousoutzanis, Ruxandra Trandafoiu and Aybige Yilmaz. New York: Peter Lang.

(Figure 4), prejudiced portrayals of African music culture that reaffirm Orientalist concepts of African musics to be traditional, not modern, and thus authentic. Representations of musical instruments conjure powerful associations with otherness the more they differ (by Western standards) in shape, size, decoration or playing technique and the more they remain unspoiled by Western influences, thus are evocative of unusual and exotic otherness depending on the level of perceived cultural purity. Yet such markers of cultural (racial, ethnic) difference connoting specific ethical (orientalist) values in the representations of Africanness in multicultural/cosmopolitan cities indeed challenge the fact that 'ethnic cultures do not stand still to be photographed, analysed and measured' (Keith 2005: 11).

\section{$<$ INSERT FIGURE 4 HERE>}

Figure 4. Still from Liverpool: World in One City (2002), here depicting African drums made from natural resources and half-dressed dark-skinned musicians (courtesy of River Rich Media).

In all of the above examples, Liverpool's cosmopolitan identity was mediated via an emphasis on ethnicity, which is based on the romanticised idea that cultural difference, as personified by 'multi-ethnic' musicians and artists, is being embraced in the city's celebrations of diversity and inclusivity. Yet as already mentioned earlier, a kind of inclusive cosmopolitanism was also evoked in regards to class through mediating representations of 'Scouse' identity and the social stereotyping of Scousers. For instance, in the marketing film Liverpool: World in One City, the inclusion of Liverpool comedian actor Ricky Tomlinson during a short, satirical 'intermission' (accompanied by merry-go-round-type music) that briefly breaks up the film's serious focus on Liverpool's art, museum and music scenes serves to reference the local working classes and Scouse humour and convey 'an inclusive, 'democratizing' message that all Liverpudlians, irrespective of class, educational background, or communication skills, have a stake in the Capital of Culture enterprise' (Roberts 2010: 205). Such representations indeed help to create and sustain the image of Scousers as friendly and naturally funny (Boland 2008), whilst perceptions of 'pugnacious Scousers' and 'shellsuited scallies' were deliberately downplayed in official representations of the city. 
[forthc. 2014]. "The Cosmopolitan City: Music and Mediation during the European Capital of Culture Event". In Media and Cosmopolitanism, edited by Aris Mousoutzanis, Ruxandra Trandafoiu and Aybige Yilmaz. New York: Peter Lang.

Stereotypical representations of Scousers as outwardly friendly also crossed the age and gender divide, even though these seemed underpinned by stereotypical views of Scouse 'lads and wags' as being 'a bit thick', further accentuated by associations with the peculiar Scouse accent. For instance, former Big Brother celebrity Craig Phillips is depicted in the marketing film unable to communicate the phrase 'Good luck to Liverpool for Capital of Culture', whilst the three members of Atomic Kitten are seen in 'girly' attire and pose and slightly orange-tinted skin tone (associated with working class or (worse) chav culture in Britain) (Figure 5) shouting to the camera: '.... We would just like to say big big shout out for Capital of Culture. See you later!' [followed by a high-pitched Oooooh and frantic waving].

\section{$<$ INSERT FIGURE 5 HERE>}

Figure 5: Still from Liverpool: World in One City (2002) featuring Liverpool pop group Atomic Kitten (courtesy by River Rich Media).

Yet Liverpool's new city brand was not exclusively defined by its cosmopolitan identity. As the narrative of the marketing film moves through art, music, sport, education and new media to evoke Liverpool as a culturally dynamic and inclusive city, the film suddenly moves towards an image of Liverpool as a place and space for postmodern consumption and lifestyle. Here cosmopolitanism becomes entangled in complex and problematic ways:

Vibrant street culture and fashion, unrivalled nightlife and Cream, its very own super-brand, coupled with an amazing choice of retail, hotel, bar, music and entertainment venues make Liverpool a super-charged cosmopolitan cultural capital. (Cathy Tyson, River Media 2002)

In this melange of street and shop signs, famous music venues and global brand logos, the act of consumption and lifestyle is foregrounded as the preeminent marker of Liverpool's urban renaissance, epitomised by the Liverpool One development, one of the largest retail developments in Europe. The mediation, packaging and selling of brand Liverpool as a place and space of consumption reflects the culture economy approach to urban development where 
[forthc. 2014]. "The Cosmopolitan City: Music and Mediation during the European Capital of Culture Event". In Media and Cosmopolitanism, edited by Aris Mousoutzanis, Ruxandra Trandafoiu and Aybige Yilmaz. New York: Peter Lang.

culture becomes a crucial resource in the post-industrial economy of deindustrialising cities, as is reflected in the use of cultural heritage in the development policies of the European Union more widely (Richards 2000). It is within this context of global consumer capitalism and consumption in which Liverpool's rebranded image as cosmopolitan city must be understood.

\section{Cosmopolitanism in the Post-Industrial City}

Cosmopolitanism is a particularly relevant and useful term as it helps us move away from grasping globalisation as a single system and towards more 'scalar' thinking about the multiplicity of global (social and cultural) processes as these are marked by cultural and institutional specificity (Delanty 2006: 27; Stokes 2007: 5-6). An 'early' type of cosmopolitanism involves the philosophical cosmopolitanism referred to by Immanuel Kant who stressed the need for a world community and world governance based on the notion of human interdependency and shared morality, purporting a particular stance towards difference characterised by openness to and tolerance of diversity and otherness. More recently, relevant discourse on cosmopolitanism comes from sociology with a (frequent) differentiation made between 'true/real' cosmopolitanism and 'banal/trivial' cosmopolitanism to include consumption-based cosmopolitanism (Scheibel 2012: 5-8), marked by 'acquisitive consumption, and the control of others' (Stokes 2007: 10). ${ }^{13}$ These types of cosmopolitanism have little to do with Immanuel Kant's liberal-enlightenment discourse, and yet the latter is particularly pertinent for my discussions in the context of branding post-industrial Liverpool as a cosmopolitan city.

Liverpool, 'the most cosmopolitan of Victorian cities..., the most significant ethnic 'enclave' in Victorian Britain' (Belchem 2005: 147) has always been celebrated as a cosmopolitan city, already expressed in the nineteenth century when Liverpool's port - the gateway to the empire - brought seafarers and migrants from all over the world to the city during the height of British imperialism (Belchem and MacRaild 2006: 311). It was specifically in the context of the abolition of slavery that Liverpool developed a new positive image as 'Liverpolis', a human entrepôt, 'a city state of the modern age dedicated to commerce, culture and cosmopolitan civilisation' (Belchem 2007: 49), as it resonated with Enlightenment's philosophical cosmopolitanism. This form of diasporic cosmopolitanism rooted in its 
[forthc. 2014]. "The Cosmopolitan City: Music and Mediation during the European Capital of Culture Event". In Media and Cosmopolitanism, edited by Aris Mousoutzanis, Ruxandra Trandafoiu and Aybige Yilmaz. New York: Peter Lang.

Victorian glory days was clearly at the centre of Liverpool's contemporary place brand prior to and during the ECOC, as has been shown in the previous sections, even though Liverpool is nowadays one of the least ethnically diverse British cities and characterised by a history of troubled racialised relations that began to (re)emerge during the twentieth century Edwardian period. Having witnessed a period of economic prosperity since the 1990s through the city's place marketing efforts, Liverpool indeed remains an acutely polarised city on key-socioeconomic indicators, whilst its geographic inequalities are actually increasing (Boland 2008: 357). Some critics have thus raised questions as to whether the ECOC title would help Liverpool to 'regain its creative cosmopolitanism of the past' so as to 'attract the highly mobile "creative classes" regarded... as the key drivers of economic growth in the postindustrial city' (Belchem 2007: 55).

It is indeed within the context of neo-liberal and entrepreneurial urbanisms, which 'commonly ground notions of cosmopolitanism in the planning, remodelling and reimaging of the "post-industrial" city' (Young, Diep and Drabble 2006: 1688) that Liverpool ECOC must be placed, and this has consequences for dealing with difference. For instance, while some neo-liberal interpretations (including the writers of the ECOC bid) may dream of the ideal Liverpolis/Cosmopolis, 'a city... in which there is genuine acceptance of, connection with, and respect and space for the cultural other, and... the possibility of a togetherness in difference' (Sandercock 2003: 2), there is evidence to suggest that neo-liberal and entrepreneurial policy territorialises difference and normalises 'acceptable' and 'unacceptable' others, and thereby reinforces the binary opposition between self and other informed by the contested politics of class, race and gender.

Meanwhile, within the context of European cosmopolitanism, there exists a clear paradox between the persistence of Enlightenment culturalism and ethical universalism that often leads towards the rejection of those who are inadequately cosmopolitan (Calhoun 2009: 649). A remodelling and reimaging of the post-industrial city may thus lead to exclusion, marginalisation and disempowerment of certain individuals and groups of people, where the middle-class gentrified lifestyles exist 'in a bubble' and otherness is valued 'as a kind of social wallpaper' (Young, Diep and Drabble 2006: 1690-91), and where some 'local inhabitants may end up feeling that they are part of an extravagant "show" being staged 
[forthc. 2014]. "The Cosmopolitan City: Music and Mediation during the European Capital of Culture Event". In Media and Cosmopolitanism, edited by Aris Mousoutzanis, Ruxandra Trandafoiu and Aybige Yilmaz. New York: Peter Lang.

primarily for the benefit of tourists' (Richards 2000: 179). In the context of Liverpool ECOC, the narrative spun around slogans like 'Liverpool as a city of contrast', 'Liverpool, city of many faces', 'a myriad of cultures' and 'The World in One City', alongside representations of difference and otherness as outlined throughout the chapter, would indeed support such criticisms. $^{14}$

This type of cosmopolitanism may be termed post-industrial cosmopolitanism in order to differentiate it from other expressions of cosmopolitanism. ${ }^{15}$ Post-industrial cosmopolitanism exists within the context of neo-liberal transformation in an effort to 're-cosmopolitanise' the city (Stokes 2007: 8). It captures more recent efforts to develop the cultural city via place marketing and branding, with marketing strategies commonly underpinned by neo-Kantian cosmopolitan values in order to counter negative stereotypes and perceptions, and to make cities more appealing to investors, tourists, consumers and residents.

\section{Conclusion}

This chapter has illustrated the rebranding of post-industrial Liverpool as a cosmopolitan city - The World in One City - prior to and during its celebrations as a European Capital of Culture in 2008, while placing specific focus on mediated knowledge as it sought to form cosmopolitan memories of remarkable and symbolically important places and events associated with the city of Liverpool. The emphasis on mediation is significant here, as almost all knowledge of the world is a knowledge entirely mediated, and consequently our understanding of the world is built largely on constructive representations by the media industries (Hall 1997). The focus on mediation is also important, as an integral component of Liverpool's ECOC status involved its (mediated) marketing and promotional strategy, whose main objective was the promotion of the city and its image.

The European Capital of Culture event is thus firmly rooted within the current age of city marketing, reflected in the shift since the 1980s away from purely cultural and towards economic and urban regeneration goals in order to rebrand culturally-deprived and deindustrialising cities like Liverpool as a postmodern 'consumerscape' (Roberts 2010: 200) so as to attract the mobile postmodern consumer and harness cultural tourists (Krüger 2013; Richards 2000). Such event-led cultural and economic policies by the European Union are 
[forthc. 2014]. "The Cosmopolitan City: Music and Mediation during the European Capital of Culture Event". In Media and Cosmopolitanism, edited by Aris Mousoutzanis, Ruxandra Trandafoiu and Aybige Yilmaz. New York: Peter Lang.

marked by a more economic view of cultural policy aimed at economic growth and the attraction of inward investment. In the case of Liverpool, official agendas were underpinned by neo-Kantian ethical universalism and humanitarian values with an emphasis on community access and participation, and celebrations of cultural diversity and inclusivity. In doing so, the official promotional materials indeed served to rebrand Liverpool as an inclusive festive city representative of neo-Kantian cosmopolitanism - a carnivalesque utopia - that framed culture in more socially-directed ways (see also Hughes 1999; Krüger 2013: 152-54).

Yet official place branding initiatives via media and promotional strategies are 'highly selective and sanitised to satiate external audiences' (Boland 2008: 366-7) and often lead to stereotyped representations of places that construct and reinforce a certain acceptable image of the city. Thus whilst 'middle and upper class elites easily fit the standard definition of cosmopolitanism as embracing mobility, flexibility, diversity, urbanity, and modernity' (Silverman 2007: 336), others may not readily fit this image (see, e.g., Andersson 2011; Nassy Brown 2005; Webster 2008), and thus remain less readily visible in official narratives and representations, a 'process of making visible/invisible' that raises questions about the relation of power and representation (Keith 2005: 4): ${ }^{16}$

... the city has a biography that suffers always from the unreliable and imperfect flaws of the narrator... [and] histories are normally written by the winners, the voices of the dispossessed relegated to the marginalia. (Keith 2005: 14)

In other words, place rebranding can lead to oversimplification and stereotyping of places, produce sameness, and reflect what powerful groups imagine and construct as the acceptable image of the city, most notably affecting those groups and areas in the city that are regarded as 'exotic' (e.g., multicultural) and white working class. ${ }^{17}$ As a result, the new place brand tends to favour an 'official culture' (Jones and Wilks-Heeg 2004: 353) and mediate representations that strengthen some forms of culture, whilst pushing others towards the margins (Lähdesmäki 2009: 217). Consequently, city remodelling and reimaging mediates, engineers and packages difference and otherness that is informed most notably by the politics of race, class and other cultural difference, and this reimaging is at times contested by local 
[forthc. 2014]. "The Cosmopolitan City: Music and Mediation during the European Capital of Culture Event". In Media and Cosmopolitanism, edited by Aris Mousoutzanis, Ruxandra Trandafoiu and Aybige Yilmaz. New York: Peter Lang.

residents who feel culturally excluded from the new (white) middle-class image portrayed, and who 'regard[s] this cosmopolitan partying with distaste' (Stokes 2007: 8).

The rebranding of Liverpool as a cosmopolitan festival city may thus be scorned as nothing more than providing the official gloss in the city's role as ECOC in promoting a 'sloppy feelgood rhetoric of melting-pot harmony' (Keith 2005: 8). Romanticised virtues of a civil society and community mobilisation, as mediated in Liverpool ECOC, deliberately distract away from actual injustices, such as racial segregation, and with it, social, economic, and cultural exclusion of certain ethnic communities (e.g., Brown 2005). Moreover, place rebranding fails to reflect the full realities of life in the city, with much of the official narrative mediating brand Liverpool as a place and space for hyper-consumption and touristic spectacle. Thus even while some critics suggest that 'the rhetoric of social inclusion is not necessarily at odds with a liberal economic development agenda' (Griffiths 2006: 428), it appears that post-industrial cosmopolitanism - and, with it, the neo-liberal illusion of equal access-poses serious concerns about the uneven nature of post-industrial capitalist development.

\section{References}

08 Liverpool European Capital of Culture. 2008. Official Liverpool 08 Yearbook. Liverpool: Liverpool City Council.

Anderson, Elijah. 2004. 'The Cosmopolitan Canopy'. The ANNALS of the American Academy of Political and Social Science 595: 14-31.

Anderson, Ben and Adam Holden. 2008. 'Affective Urbanism and the Event of Hope'. Space and Culture 11(2): 142-159.

Andersson, Emma. 2011. 'African Musics in Liverpool: An Ethnographic Study'. Unpublished MRes Thesis, School of Art and Design. Liverpool: Liverpool John Moores University. 
[forthc. 2014]. "The Cosmopolitan City: Music and Mediation during the European Capital of Culture Event". In Media and Cosmopolitanism, edited by Aris Mousoutzanis, Ruxandra Trandafoiu and Aybige Yilmaz. New York: Peter Lang.

Appadurai, Arjun. 1990. 'Disjuncture and Difference in the Global Cultural Economy'. Theory, Culture, Society 7: 295-310.

Barthel-Bouchier, Diane and Ming Min Hui. 2007. 'Places of Cosmopolitan Memory'. Globality Studies Journal 5 [no pp.]. Available at http://globality.cc.stonybrook.edu/?p=66, accessed 8 January 2014.

Beck, Ulrich and Edgar Grande. 2010. 'Varieties of Second Modernity: The Cosmopolitan Turn in Social and Political Theory and Research'. The British Journal of Sociology 61(3): 409-443.

Belchem, John. 2005. 'Whiteness and the Liverpool-Irish'. Journal of British Studies 44(1): 146-152.

Belchem, John. 2007. 'Liverpool: World City'. History Today April: 48-55.

Belchem, John and Donald M. MacRaild. 2006. 'Cosmopolitan Liverpool'. In Liverpool 800: Culture, Character \& History, edited by John Belchem, 311-391. Liverpool, UK: Liverpool University Press.

Boland, Philip. 2008. 'The Construction of Images of People and Place: Labelling Liverpool and Stereotyping Scousers'. Cities 25: 355-369.

Brocken, Michael. 2010. Other Voices: Hidden Histories of Liverpool's Popular Music Scene, 1930s-1970s. Aldershot: Ashgate.

Calcutt, Lyn, Ian Woodward and Zlatko Skrbis. 2009. 'Conceptualising Otherness: An Exploration of the Cosmopolitan Schema'. Journal of Sociology 45(2): 169-186. 
[forthc. 2014]. "The Cosmopolitan City: Music and Mediation during the European Capital of Culture Event". In Media and Cosmopolitanism, edited by Aris Mousoutzanis, Ruxandra Trandafoiu and Aybige Yilmaz. New York: Peter Lang.

Calhoun, Craig. 2009. 'Cosmopolitan Europe and European Studies'. In The Sage Handbook of European Studies, edited by Chris Rumford, 637-654. London: Sage.

Cohen, Sara. 1991. Rock Culture in Liverpool: Popular Music in the Making. Oxford: Oxford University Press.

2007. Decline, Renewal and the City in Popular Music Culture: Beyond the Beatles. Aldershot: Ashgate.

2012. 'Musical Memory, Heritage and Local Identity: Remembering the Popular Music Past in a European Capital of Culture'. International Journal of Cultural Policy 19(5): 576-594.

Delanty, Gerard. 2006. 'The Cosmopolitan Imagination: Critical Cosmopolitanism and Social Theory'. The British Journal of Sociology 57(1): 25-47.

Delanty, Gerard. 2008. 'The Cosmopolitan Imagination'. Revista Cidob D'Afers Internacionals 82-83: 217-230.

Dinnie, Keith. 2004. 'Place Branding: Overview of an Emerging Literature'. Place Branding 1(1): 106-110.

Du Noyer, Paul. 2007. Liverpool Wondrous Place: From the Cavern to the Capital of Culture. London: Virgin Books.

ECOTEC. 2009. Ex-Post Evaluation of 2007 and 2008 European Capitals of Culture: Final Report. Birmingham: ECOTEC.

http://ec.europa.eu/dgs/education_culture/evalreports/culture/2009/capital_en.pdf, Accessed 21 January 2013. 
[forthc. 2014]. "The Cosmopolitan City: Music and Mediation during the European Capital of Culture Event". In Media and Cosmopolitanism, edited by Aris Mousoutzanis, Ruxandra Trandafoiu and Aybige Yilmaz. New York: Peter Lang.

Evans, Graeme. 2003. 'Hard-Branding the Cultural City - From Prado to Prada'. International Journal of Urban and Regional Research 27(2): 417-440.

Garcia, Beatrix, Ruth Melville, and Tamsin Cox. 2010. Creating an Impact: Liverpool's Experience as European Capital of Culture. Impacts 08. Accessed 16 January 2013. http://www.liv.ac.uk/impacts08/Papers/Creating_an_Impact_-_web.pdf.

Griffiths, Ron. 2006. 'City/Culture Discourses: Evidence From the Competition to Select The European Capital of Culture 2008'. European Planning Studies 14(4): 415-430.

Hall, Stuart. 1997. 'The Work of Representation'. In Representation: Cultural Representations and Signifying Practices (Culture, Media and Identities Series), edited by Stuart Hall, 13-74. London: Sage.

Haller, William and Victor Roudometof. 2010. 'The Cosmopolitan-Local Continuum in Cross-National Perspective'. Journal of Sociology 46(3): 277-297.

Hjortegaard Hansen, R. 2010. 'The Narrative Nature of Place Branding'. Place Branding and Public Diplomacy 6: 268-279.

Hughes, George. 1999. 'Urban Revitalization: The Use of Festive Time Strategies'. Leisure Studies 18(2): 119-135.

Isaac, Sir Jeremy. 2003. 'Report on the short-listed Applications for the UK Nomination for European Capital of Culture 2008'. Issued by the Department for Culture Media and Sport, on behalf of The Independent Advisory Panel for the UK Nomination for European Capital of Culture 2008.

Jenkins, Henry. 2006. 'Pop Cosmopolitanism: Mapping Cultural Flows in an Age of Media Convergence'. In Fans, Bloggers and Gamers: Exploring Participatory Culture, 152-172. New York: New York University Press. 
[forthc. 2014]. "The Cosmopolitan City: Music and Mediation during the European Capital of Culture Event". In Media and Cosmopolitanism, edited by Aris Mousoutzanis, Ruxandra Trandafoiu and Aybige Yilmaz. New York: Peter Lang.

Jones, Paul and Stuart Wilks-Heeg. 2004. 'Capitalising Culture: Liverpool 2008'. Local Economy 19(4): 341-360.

Keith, Michael. 2005. After the Cosmopolitan? Multicultural Cities and the Future of Racism. New York: Routledge.

Krüger, Simone. 2013. 'Branding the City: Music Tourism and the European Capital of Culture Event'. In The Globalization of Musics in Transit: Music Migration and Tourism, edited by Simone Krüger and Ruxandra Trandafoiu, 135-159. New York: Routledge.

Langen, Floris and Beatriz Garcia. 2009. Measuring the Impacts of Large Scale Cultural Events: A Literature Review. Impacts 08. Accessed on 15 January 2013. www.liv.ac.uk/impacts08/.

Lähdesmäki, Tuuli. 2009. 'Concepts of Locality, Regionality and Europeanness in European Capitals of Culture.' In Representation, Expression and Identity: Interdisciplinary Perspectives, edited by T. Rahimy. Oxford: Inter-Disciplinary Press. htp://www.interdisciplinary.net/wp-content/uploads/2009/11/rei-v1.3b.pdf, accessed 17 March 2013..

LCC (Liverpool City Council). 2008. The Art of Inclusion: Liverpool's Creative Community. Commissioned by Liverpool City Council.

LCCL (Liverpool Culture Company Limited). 2002. Executive Summary. http://www.liverpool08.com, accessed 27 October 2013.

Madsen, Henrik-. 1992. 'Place-Marketing in Liverpool: A Review'. International Journal of Urban and Regional Research 16(4): 633-640.

Nassy Brown, Jacqueline. 2005. Dropping Anchor, Setting Sail: Geographies of Race in Black Liverpool. Princeton: Princeton University Press. 
[forthc. 2014]. "The Cosmopolitan City: Music and Mediation during the European Capital of Culture Event". In Media and Cosmopolitanism, edited by Aris Mousoutzanis, Ruxandra Trandafoiu and Aybige Yilmaz. New York: Peter Lang.

Nobili, Valentina. 2005. 'The Role of European Capital of Culture Events within Genoa's and Liverpool's Branding and Positioning Efforts'. Place Branding 1(3): 316-328.

Richards, Greg. 2000. 'The European Capital of Culture Event: Strategic Weapon in the Cultural Arms Race?' Journal of Cultural Policy 6(2): 159-181.

River Media. 2002. Liverpool: World in One City [promotional video accompanying the ECOC bid]. Commissioned by Liverpool City Council.

Roberts, Les. 2010. 'World in One City: Surrealist Geography and Time-space Compression in Alex Cox's Liverpool'. Tourism and Visual Culture, Vol. 1: Theories and Concepts, edited by P. Burns, C. Palmer and J-A. Lester, 200-215. CABI.

Qassim, Samira and Saria Hassan. 2009. The Liverpool Arabic Centre: A History. Provided to the author by Taher Qassim; http://www.liverpoolarabiccentre.org.uk/, accessed 12 March 2013.

Said, Edward W. 1978. Orientalism. United States: Pantheon Books.

Sandercock, Leonie. 2003. Cosmopolis II. Mongrel Cities of the 21 ${ }^{\text {st }}$ Century. London: Continuum.

Scheibel, Saskia. 2012. 'Against all Odds: Evidence for the 'True' Cosmopolitan Consumer. A Cross-Disciplinary Approach to Investigating the Cosmopolitan Condition'. Master Dissertation. London: University of London.

Silverman, Carol. 2007. "Trafficking in the Exotic with "Gypsy" Music: Balkan Roma, Cosmopolitanism, and "World Music" Festivals'. In Balkan Popular Culture and the Ottoman Ecumene: Music, Image, and the Regional Political Discourse, edited by Donna A. Bucharan, 335-363. Lanham, Maryland: Scarecrow. 
[forthc. 2014]. "The Cosmopolitan City: Music and Mediation during the European Capital of Culture Event". In Media and Cosmopolitanism, edited by Aris Mousoutzanis, Ruxandra Trandafoiu and Aybige Yilmaz. New York: Peter Lang.

Stokes, Martin. 2007. 'On Musical Cosmopolitanism'. The Macalester International Roundtable 2007. Paper 3. http://digitalcommons.macalester.edu/intlrdtable/3. Accessed 10 September 2013.

Ward, Stephen Victor, 1998. Selling Places: The Marketing and Promotion of Towns and Cities, 1850 - 2000. London: E \& FN Spon.

Webster, Colin. 2008. 'Marginalized White Ethnicity, Race and Crime'. Theoretical Criminology 12(3): 293-312.

Wilks-Heeg, Stuart. 2003. 'From World City to Pariah City? Liverpool and the Global Economy, 1850-2000'. In Reinventing the City? Liverpool in Comparative Perspective, edited by Ronaldo Munck, 36-52. Liverpool: Liverpool University Press.

Young, Craig, Martina Diep and Stephanie Drabble. 2006. 'Living with Difference? The “Cosmopolitan City" and Urban Reimaging in Manchester, UK'. Urban Studies 43(10): 1687-1714.

\section{Notes}

1 In terms of the procedure for selection, the European Commission assigns each member state a year in which to nominate one of its cities for the ECOC title. The UK was assigned the year 2008, and twelve UK cities submitted applications to the Department for Culture, Media and Sport by the closing date (31 March 2002), namely Belfast, Birmingham, Bradford, Brighton and Hove, Bristol, Canterbury, Cardiff, Inverness, Liverpool, Newcastle-Gateshead, Norwich and Oxford. The selection process was two-staged, first involving the selection of six shortlisted cities and secondly selecting the winning city, Liverpool (see further Griffiths 2006:419; Isaac 2003).

2 Through The Mersey Partnership and later Liverpool Vision, city administrators have since the 1990s sought to improve the city's image, which had since the 1960s developed a negative reputation for radical trade unionism, race riots, left-wing radicalised and financially irresponsible 
[forthc. 2014]. "The Cosmopolitan City: Music and Mediation during the European Capital of Culture Event". In Media and Cosmopolitanism, edited by Aris Mousoutzanis, Ruxandra Trandafoiu and Aybige Yilmaz. New York: Peter Lang.

city administration, and football hooliganism, which collectively brought significant negative media coverage of the city as being 'strike-bound, bankrupt, run-down, wasted, hopeless and run by loony left-wingers' (Madsen 1992:634).

3 The bid to win the ECOC title was first conceived in 1999 by Liverpool City Council and various members of the arts and academic sectors. The Directors of the Liverpool Culture Company included Kris Donaldson as Director, Claire McColgan as Executive Producer responsible for the public involvement programmes, and Fiona Gasper as Executive Producer responsible for the development and delivery of the arts programmes. See also http://www.liverpoolculture.com/about/Directors/index.asp, accessed 11 March 2014.

4 The ethnographic data collection included interviews with city council officials (e.g., Liverpool City Council and the Liverpool Culture Company); researchers of the Impacts 08 team; executive members of local cultural organizations like the Beatles Museum, Liverpool Philharmonic, FACT, Tate, Bluecoat, etc.; and local musicians, composers, and audiences, including local people from all sorts of backgrounds. I also completed participant observation at a vast number of music concerts, events, performances, festivals, exhibitions, museums, theatres, etc. I also collected a vast amount of print materials in the form of promotional material published by Liverpool City Council, Liverpool Culture Company Limited and Impacts 08; media coverage in local and national newspapers; websites; and flyers and other non-commericalised publications. However, this chapter has as its main focus mediation and thus is less concerned with ethnography. For interesting examples of urban ethnography in two different geographical locations see Anderson (2004) and Cohen (2012).

5 For a useful literature review on the concept of the 'cosmopolitan city', see Young, Diep and Drabble (2006).

6 The community engagement programme was led by Claire McColgan who joined the Liverpool Culture Company in 2000 and created and managed the cultural programme for the public involvement in the Capital of Culture bid which was cited as the major factor in Liverpool's success. More specifically, McColgan designed, produced and managed the unique Creative Communities Programme from inception to execution.

7 The film was produced in 2002 by River Media, an influential company that shaped much of Liverpool City Council's visual communication and marketing discourses and one of Liverpool's leading media production companies (Roberts 2010:202). The company now exists under the name of River Rich Media (see http://www.rivermotiongroup.com/index.html, accessed 21 October 2013). 
[forthc. 2014]. "The Cosmopolitan City: Music and Mediation during the European Capital of Culture Event". In Media and Cosmopolitanism, edited by Aris Mousoutzanis, Ruxandra Trandafoiu and Aybige Yilmaz. New York: Peter Lang.

8 The 8 -min marketing film is comprised of 525+ edits, rendering it a radically fast-cut montage of visual and audio shots.

9 Since 2012, the annual Brazilian festival and samba carnival is known as Brazilica festival (see http://www.brazilicafestival.co.uk/, accessed 27 October 2013).

10 The Liverpool Commissions strand was led by Nick Birkinshaw (he also project managed the opening events on 11 and 12 January 2008), and included fourteen projects of up to $£ 50,000$ each (with an overall budget of $£ 500,000$ ) in a celebration of 'dance, site specific experimental performances in unique buildings, technical exploration, water art, explosive new music and film, ships and boats, soundscapes, dub, digital platforms, football, theatre, cabaret, orchestras, and pub singers' (The Liverpool Commissions booklet 2008, provided to author by Nick Birkinshaw). From 150 expressions of interest, 45 projects were shortlisted for a detailed project proposal, from which the following fourteen projects were chosen: 1. Anima by Momentum; 2. The Potting Shed Cabaret by Walk the Plank; 3. Twilight City by the Hive Collective; 4. The Shankly Show by Footballing Legends Ltd; 5. The Line by Collision; 6. Spirit on the Water by Jump Ship Rat; 7. Open Source City by Sound Network; 8. Chinese Dub/Jah Wobble by 30 Hertz; 9. High Hopes by First Take and Sydvest Films; 10. Audio Vision by Kinetophone Records and Kinetic Fallacy; 11. Phil Collins Residency at A Foundation; 12. Babul and the Blue Bear by 20 Stories High; 13. The Quiet Little Englishman by Zho Visual Theatre; 14. The Rightful Owners of the Song by Jonathan Raisin.

11 See also Beck and Grande 2007 on Europe's so-called 'privileged relationship with cosmopolitanism' (Haller and Roudometof 2010: 281).

12 Although Africa Oyé's line-up usually consists of international African music groups (from the African continent and diaspora), in 2008 it also featured Oludele Olaseinde's River Niger Orchestra. Even so, the presence of local African musicians was only marginal during 2008, whilst many African musicians remained in the periphery.

13 For useful overviews on cosmopolitanism from sociology, see also Beck and Grande (2010: 41719); Calcutt, Woodward and Skrbis (2009: 170-72); Delanty (2006: 28-36).

14 In the context of cosmopolitan Europe, Craig Calhoun further contends that in such struggles, seemingly anti-cosmopolitan resistance is often a weapon of those in danger of intensified exploitation by dominant interests... But equally, extensions of transnational power and capitalist markets can also inform fears that fuel populist reactions against immigrants... from citizens who 
[forthc. 2014]. "The Cosmopolitan City: Music and Mediation during the European Capital of Culture Event". In Media and Cosmopolitanism, edited by Aris Mousoutzanis, Ruxandra Trandafoiu and Aybige Yilmaz. New York: Peter Lang.

feel that their citizenship buys them less and less protection from global threats and less and less participatory democracy.' (Calhoun 2009:651)

15 More recently, the academic literatures usefully differentiate between different types of cosmopolitanism to denote the various ways in which difference and otherness are regarded and understood. Sociologists Gerard Delanty, for instance, argues that 'The very notion of cosmopolitanism compels the recognition of multiple kinds of cosmopolitanism, including earlier kinds of cosmopolitanism, and which cannot be explained in terms of a single, western notion of modernity or in terms of globalization' (2006: 27). With specific focus on music, Martin Stokes identifies at least five musical cosmopolitanisms: (a) an elite, intelligentsia cosmopolitanism rooted in nineteenth and early twentieth century nation-state building projects that constructed national art and folk musics from musical syncretisms blending local folk with modern/western musics; (b) a popular cosmopolitanism, a sub-category of the previous type that is historically and spiritually rooted; (c) a mass-mediated cosmopolitanism based on recent pop star collaborations with 'world' musicians, which are often (dis)regarded in academic circles as musical prolongation of nineteenth century orientalism by musical neo-orientalists for a western market in exotica; (d) a migrant cosmopolitanism as it is produced by the urban poor-migrants - in opposition to the neoliberal transformations of cities and associated place-branding projects that 're-cosmopolitanise' the global city as urbane, cosmopolitan, multi-cultural, tolerant, and so forth; and (e) a diasporic cosmopolitanism that takes into account the contribution made by diasporans towards collective fantasies, ideologies and identities (Stokes 2007:7-10). Meanwhile, Henry Jenkins uses the term pop cosmopolitanism to describe the embrace of global popular media, including music, as a kind of escape from real life and inspiration for new forms of global consciousness and cultural competency (Jenkins 2006).

16 My ethnographic data collection contains concrete evidence to support this claim, which draws on numerous interviews with local musicians and artists alongside participant observations during non-funded musical initiatives, such as the musical The Liver Bird Sang written and performed for the city's ECOC celebrations, yet to report the findings from my ethnographic research is beyond the scope of this chapter.

17 Indeed, some forms of difference, notably white working class culture and areas that are not deemed commodifiable and acceptable were not supported or funded, and did not feature in the official mediated representations. 